\title{
Impacts of Tourism on Marine Debris and Microplastic Detection at Samui Island, Southern Thailand
}

\section{Horpet, P. ${ }^{\text {a }}$, Jaroensutasinee, M. ${ }^{\text {, }}$, Jaroensutasinee, K. ${ }^{\text {c }}$}

${ }^{a}$ Marine Science Program, School of Science, Walailak University 222 Thasala, Nakhon Si

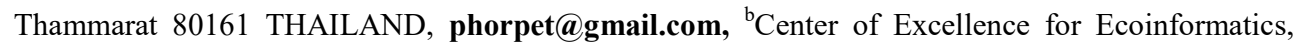
School of Science, Walailak University 222 Thasala, Nakhon Si Thammarat 80161 THAILAND, mullica.jn@gmail.com, 'Center of Excellence for Ecoinformatics, School of Science, Walailak University 222 Thasala, Nakhon Si Thammarat 80161 THAILAND, krisanadej@gmail.com.

\begin{abstract}
We investigated types, amounts and sources of marine debris and microplastics, and compared how tourism, by means of different levels of beach cleanup, affecting them. We collected marine debris and microplastics at three beaches based on frequencies of beach cleanup: high (Chaweng Beach), intermediate (Lamai Beach) and no beach cleaning (Hua Thanon Beach). Marine debris was counted from a ground survey using the applied Trash Free Sea ${ }^{\circledR}$ data card and the International Coastal Cleanup (ICC) method. Microplastics with a size larger than $1 \mathrm{~mm}$ were examined and photographed using a clip-type mobile phone microscope. The Clean Coast Index (CCI) was used for the assessment of beach cleanliness. Over 95\% of the marine debris was plastic, and microplastics were ubiquitous, which calls for classification of the plastics as hazardous materials. Hua Thanon Beach had the highest (CCI > 20) (extremely dirty), followed by Lamai Beach (2-5 CCI) and the least CCI was at Chaweng Beach (CCI <2) (clean beach). This is because the popular tourism beach (Chaweng Beach) had the highest beach cleaning frequencies even during the 3-month lockdown of the covid19 situation. This rapid-survey method could be developed and applied for a citizen-science project on the survey of marine debris and microplastics and on monitoring the condition of our beaches.
\end{abstract}

Keywords: Marine debris, microplastic, tourism, human impacts, Clean Coast Index (CCI). 


\section{Introduction}

Coastal tourism and recreation sector plays an important role in economic bloodstreams of Thailand. This sector counts heavily on the healthy coastline and marine resources together with aesthetic quality of the environments attracting both local and foreign tourists for long term benefits. Marine debris and microplastic could be the undisputable issues to devalue our precious natural resources (UNEP, 2016). Marine debris and microplastic (plastic particles $<5 \mathrm{~mm}$ ) is a global issue that needs to be addressed urgently (Barnes et al., 2009; Depledge et al., 2013).

Thailand ranked number $6^{\text {th }}$ in the world in producing plastic debris to the Oceans (Jambeck et al., 2015). Marine debris is defined as any persistent, man-made solid waste discarded into the marine environment (Galgani et al., 2015). Most of it is made of plastic (Barnes et al., 2009) that originates from both land- and ocean-based sources which is well documented for $80 \%$ land-based source relating human activities. Ocean currents spread large amounts of debris from industrialized and densely populated areas to even the most remote and unpopulated coastal regions (McDermid and McMullen, 2004; Barnes et al., 2009; Hirai et al., 2011). Microplastics are minute fragments of plastic debris, which are divided into small $(<1 \mathrm{~mm}$ in diameter) and large (1-5 $\mathrm{mm}$ in diameter) particles (Horton et al., 2017). Microplastics consist of nylon, polyester, acrylic, poly-propylene, polyethylene, poly (ethylene-propylene), polyvinylchloride, polyvinyl alcohol, polystyrene, polyester, polyurethane, polyacrylonitrile, alkyd, alkyd resin, and polyamide fibers. The main component of microplasic is usually synthetic polymers (Barnes et al., 2009; Vianello et al., 2013).

Samui Island is one of the most tourist attraction places in Thailand where marine debris and microplastics debris could be affected by tourisms. In this study, we conducted the simple field examination to survey the type, amount and source of marine debris, and to compare how tourism, by means of different levels of beach cleanup, affecting numbers and density of (visible) microplastic debris among the study locations as well as to find correlation between marine plastic debris (on surface) and the residues of visible microplastic debris (found in sand sediment). We predicted that high beach cleanup frequency beach would have lower amounts of marine debris, microplastics and CCI. We tested our prediction on three beaches based on beach cleaning frequencies: high (Chaweng Beach), intermediate (Lamai Beach) and no beach cleaning (Hua Thanon Beach). 


\section{Materials and methods}

\subsection{Study sites}

This study was conducted at three beach fronts: Chaweng, Lamai and Hua-Thanon Beaches along the east coast of the Samui Island, Southern Thailand (Fig. 1). Chaweng Beach $\left(09^{\circ} 28^{\prime} 06^{\prime} \mathrm{N}, 100^{\circ} 02^{\prime} 58^{\prime \prime} \mathrm{E}\right)$ was a kind of private with high tourist activities, with frequent cleanup (once a day) from hotel staffs (Fig. 1 site a). Lamai Beach $\left(09^{\circ} 31^{\prime} 46^{\prime \prime} \mathrm{N}\right.$, $\left.100^{\circ} 03^{\prime} 47^{\prime \prime} \mathrm{E}\right)$ was an open-access beach with optimal numbers of tourists visiting and with regular beach cleanup (once a week) from nearby hotel staffs/ local authorities/cleanup campaign activities (Fig. 1 site b). Hua-Thanon Beach $\left(09^{\circ} 27^{\prime} 42^{\prime \prime} \mathrm{N}, 100^{\circ} 02^{\prime} 40^{\prime \prime} \mathrm{E}\right)$ was a Muslim fishing village with no beach cleanup (Fig. 1 site c).
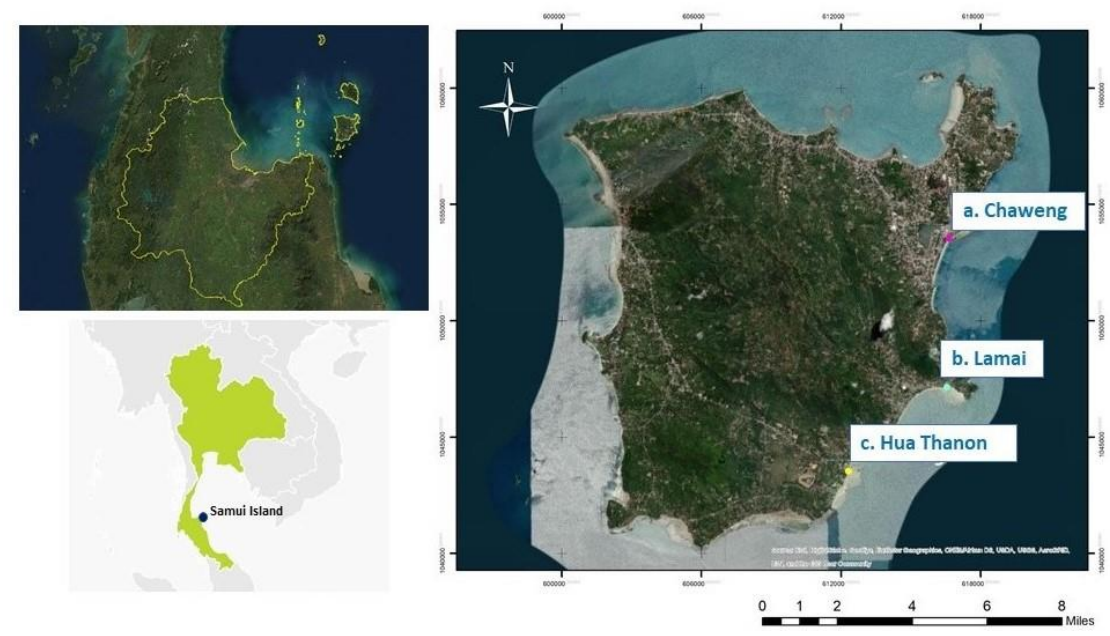

Fig. 1. Map and coordination of study sites at Samui Island, Surat Thani province, Thailand.

(a) Chaweng,(b) Lamai and (c) Hua Thanon Beaches at Samui Island, Southern Thailand.

\subsection{Data collection}

We conducted field surveys with 20-student volunteers during the peak tourist season in February 2020. Marine debris (size larger than $5 \mathrm{~mm}$ ) was collected in the $50-\mathrm{m}$ transect area ranging from the shoreline to the upper beach limit (determined by the presence of vegetation line). Sampling was performed according to the operational guidelines for rapid beach debris assessment described by the NOAA guidebook (Cheshire et al., 2009). Types, amounts and sources of marine debris were determined from a ground survey using the applied Trash Free Sea ${ }^{\circledR}$ data card and the International Coastal Cleanup (ICC) method. The Clean Coast Index (CCI) was used to assess the beach cleanliness (Alkalay et al., 2007). Marine debris was studied in the area of $250 \mathrm{~m}^{2}(\mathrm{n}=1)$ with the calculation of the CCI was equaled to the marine plastic debris concentration (B) multiplied by a constant 
number of 20 (Portman \& Brennan, 2017, see Table 1). The CCI values from 0-2 indicated very clean beaches, 2-5 clean, 5-10 moderately clean, 10-20 dirty and $>20$ extremely dirty (Portman \& Brennan, 2017).

For a possible and quick field survey of microplastic existence, the visible microplastic debris size of 1-5 mm was, therefore, examined. Three replications of about $1.5 \mathrm{~kg}$ of sand sediment were randomly collected from a $25 \times 25 \times 1 \mathrm{~cm}^{3}$. All sands were scooped by a stainless steel spoon, placed in plastic bags and sealed properly. Sand samples were oven dried at $60{ }^{\circ} \mathrm{C}$ for 1-2 hours. Microplastics debris were extracted by the use of tweezers for the analysis of the types of microplastics by hand sorting into four types: fiber, foam, film and fragment. Photos were taken by the microscope equipped with a camera.

\subsection{Data analysis}

As the assumptions of the One-Way ANOVA were not justified, a Kruskal-Wallis test with Bonferroni correction as a Post-hoc test was used to determine the difference in the density of the microplastics among the three study locations based on the different levels of beach cleanup. The level of significance was set to $p<0.05$. A linear regression analysis was used to test the association between the number of marine plastic debris and microplastics. Statistical analyses were performed with SPSS v.23 (SPSS Inc., Chicago, II., USA). A linear regression analysis was used to test the association between the number of marine plastic debris and microplastics. Statistical analyses were performed with SPSS v.23 (SPSS Inc., Chicago, II., USA). 


\section{Results and discussions}

\subsection{Marine debris and marine plastic debris}

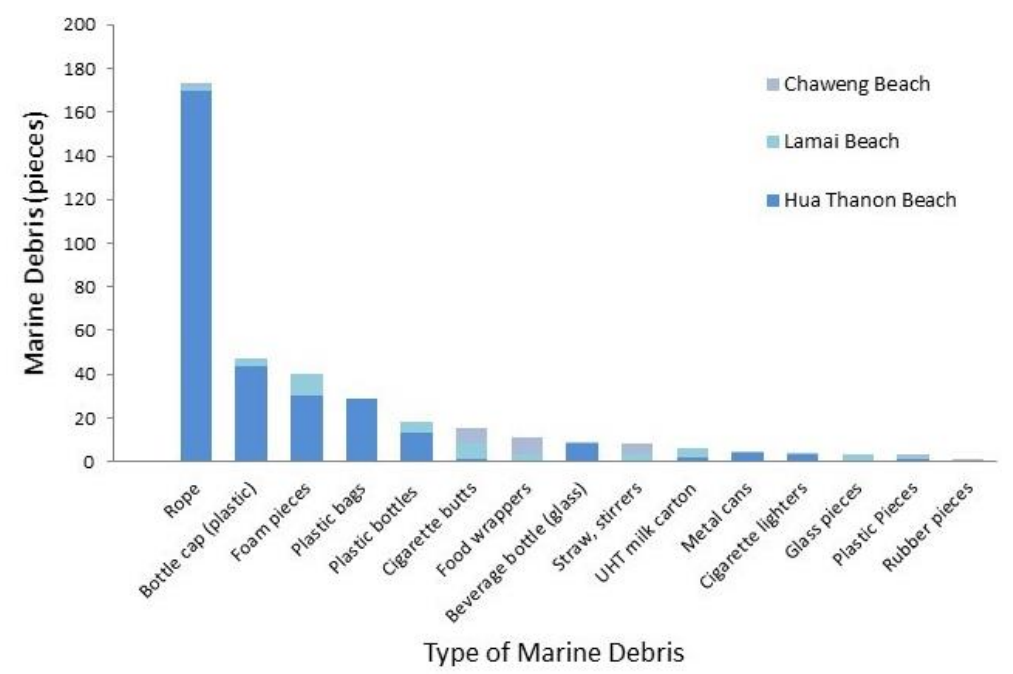

Fig. 2 Types and amounts of marine debris at three beaches at Samui Island, Southern Thailand.

There were 15 marine debris types collected from three beaches with more than $95 \%$ made of plastics (Fig. 2). Majority of marine debris were found at Hua Thanon Beach (305 items $/ \mathrm{m}^{2}$ ) followed by Lamai Beach $\left(44\right.$ items $/ \mathrm{m}^{2}$ ) and Chaweng Beach (23 items $/ \mathrm{m}^{2}$ ). With rope pieces, apprently from fishing activities, were the most items found on Hua Thanon fishing village. Excluding the rope pieces, the next top five items were bottle caps, foam pieces, plastic bags, plastic bottles and cigarette butts (Fig. 2, Table 1). The present study showed that the concentration of marine plastic debris varied in accordance with the land uses, in particular fishing or recreational activities. This observation supported with the reports of Boucher \& Friot (2017) that land-based sources were responsible for approximately $80 \%$ of marine litter.

Table 1. Amounts and concentrations of marine debris, marine plastic debris, and microplastic debris at study locations.

\begin{tabular}{|c|c|c|c|c|c|c|c|c|c|}
\hline \multirow{3}{*}{$\begin{array}{l}\text { Beach } \\
\text { areas }\end{array}$} & \multirow{3}{*}{$\begin{array}{c}\text { Date of } \\
\text { collection }\end{array}$} & \multirow{3}{*}{$\begin{array}{c}\begin{array}{c}\text { Marine } \\
\text { debris } \\
\text { (items } / \mathrm{m}^{2} \text { ) }\end{array} \\
\text { (A) }\end{array}$} & \multirow{3}{*}{$\begin{array}{c}\begin{array}{c}\text { Marine } \\
\text { plastic } \\
\text { debris }\end{array} \\
\left(\text { items } / \mathrm{m}^{2}\right)\end{array}$} & \multirow{3}{*}{$\begin{array}{l}\text { Clean } \\
\text { Coast } \\
\text { Index } \\
(\mathrm{CCI})\end{array}$} & \multicolumn{5}{|c|}{ Microplastic debris $^{* *}$} \\
\hline & & & & & \multirow{2}{*}{$\begin{array}{c}\left(\text { items } / \mathrm{m}^{2}\right) \\
\text { (C) }\end{array}$} & \multicolumn{4}{|c|}{ Shape (\% detection) } \\
\hline & & & & & & Fiber & Foam & Fragment & Film \\
\hline $\begin{array}{l}\text { Chawe } \\
\text { ng }\end{array}$ & $\begin{array}{l}\text { Feb2020 } \\
\text { May2020 }\end{array}$ & $\begin{array}{l}23(0.092) \\
n / a\end{array}$ & $\begin{array}{l}22(0.088) \\
n / a\end{array}$ & $\begin{array}{l}1.76 \\
n / a\end{array}$ & $\begin{array}{l}1(1.32) \\
7(9.32)\end{array}$ & $\begin{array}{l}0(0) \\
0(0)\end{array}$ & $\begin{array}{l}1(100) \\
0(0)\end{array}$ & $\begin{array}{l}0(0) \\
7(100)\end{array}$ & $\begin{array}{l}0(0) \\
0(0)\end{array}$ \\
\hline Lamai & Feb2020 & $44(0.176)$ & $39(0.156)$ & 3.12 & $11(14.68)$ & $1(9.10)$ & $3(27.27)$ & $7(63.63)$ & $0(0)$ \\
\hline $\begin{array}{l}\text { Hua } \\
\text { Thanon }\end{array}$ & Feb2020 & $305(1.220)$ & $293(1.172)$ & 23.44 & $73(97.32)$ & $0(0)$ & $55(73.34)$ & $17(23.29)$ & $1(1.37)$ \\
\hline
\end{tabular}


According to the beach litter, Hau Thanon Beach had the highest CCI $(>20)$ indicating an extremely dirty beach. Lamai Beach with medium cleanup activities CCI (2-5) which indicating a moderate clean beach and Chaweng Beach with the highest (once a day) cleanup activities CCI $(<2)$ indicating a very clean beach. CCI values revealed that the beach with intensive fishing activities and without cleanup contained high marine debris and microplastic in sand sediment. Our results support Barnes et al. (2009) finding that the greater loads of marine plastic debris and fragment largely came from fishing-related activities.

\subsection{Microplastic debris}

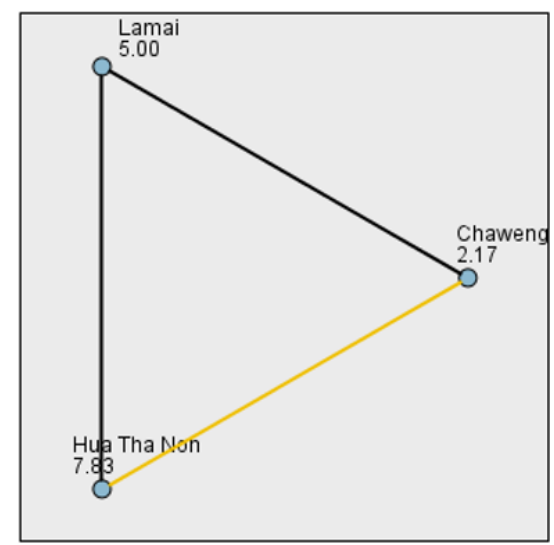

Fig. 3 Pairwise comparisons (Bonfoerroni correction) of microplastic concentrations on three beaches (Chaweng, Lamai, and Hua Thanon Beaches) at Samui, Southern Thailand, in February 2020. Each node shows the sample mean rank of the beach while the yellow line shows significant differences between pairs $(p<0.05)$.

Microplastic debris were found in all three beaches ranging between 1.32-97.32 items $/ \mathrm{m}^{2}$ (Table 1). The highest concentration of the visible microplastic debris was found at Hua Thanon Beach, and the lowest at Chaweng, the private hotel beach front. The results of a Kruskal-Wallis test were significant $(\mathrm{H}=6.587$, d.f. $=2, \mathrm{p}=0.037)$; the mean ranks of microplastic debris density were significantly different among the three beach locations. With the Bonferroni corrections as a Post-hoc test, Chaweng Beach was significantly different from Hua Thanon Beach $(p=0.031)$ (Fig. 3). There are several studies that contribute the concentration of microplastics in beach sediments to the impact of fishing and recreational activities (Davis \& Murphy, 2015; Dawarah \& Devipriya, 2019). Nevertheless, the frequent cleaning of the popular tourism beach seemed to have an effect of less marine plastic debris, including the quantity of visible microplastics detection. This 
is to further support by our additional investigation of the absence of visible microplastic debris after 3-month lockdown of the covid-19 situation in May 2020. Despite the situation, the hotel continues to perform daily beach cleanup resulting in lower density of visible microplastic concentration of 9.32 items $/ \mathrm{m}^{2}$ (Table 1).

In this present study, visible microplastics of the foam and fragment shapes come from the dominant categories of $73.34 \%$ and $23.29 \%$ consecutively. Mostly found shape of microplastic were foam which apparently reflex the broken down of larger plastic sizes. These are formed by breakdown of larger plastic through mechanical-, photo- and biodegradation as well as hydrolysis and oxidation processes (Andrady, 2011). It is, therefore, the need to remove the large plastic particles before decaying into small pieces are really vital to reduce numbers of microplastic in the beach areas such as regular beach cleanup for instance.

\subsection{Marine debris and microplastics}

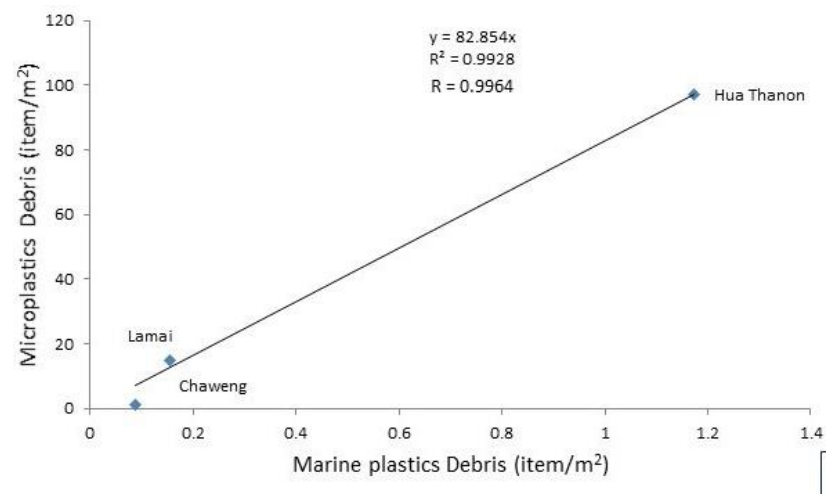

(a)

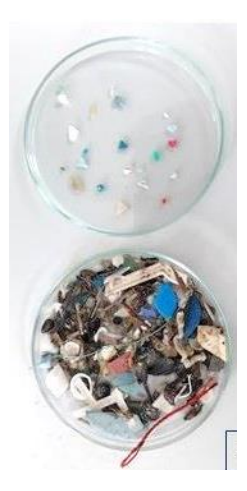

(b)

Fig. 4 (a) Correlation between marine plastic debris and microplastic debris concentrations on the beaches and (b) a size comparison between visible microplastic debris (1-5 mm) and larger marine plastic debris $(>5 \mathrm{~mm})$.

An average of 354 items of marine plastic debris and 85 of microplastic debris were observed in this study from the sandy beaches. The number of marine plastic debris was positively associated with the number of microplastic debris (Linear regression: $\mathrm{y}=$ $82.854 \mathrm{x}, F_{1,1}=188.06, R^{2}=0.993, \mathrm{p}<0.05$ ) (Fig. 4a). It clearly shows that the concentration of plastic particles are significantly high in beaches without cleaning activities. In contrast, the beach with the most cleanup frequency has the least microplastic debris in the area. Proper and complete removal of larger plastic debris can help to reduce the microplastic load in the seashore sediments. 


\section{Conclusions}

A timely assessment of marine litter, especially microplastics, will be helpful for understanding their deleterious effects, thereby proposing practical solutions. In this regard, a simple, routine and efficient monitoring of the litter should be carried out at a local scale. This will allow scientists and local partners to easily identify the changes in marine litter concentrations over time. The data on the clean-up activities and monitoring results will form the basis for organizing future work. Moreover, it is necessary to find out effective methods to reduce the risk of plastics in circulation, which end up in the coastal and marine environment. With this backdrop, in order to approach the citizen science project, we are here proposing the methods of assessment and monitoring for marine debris including microplastics, and their impact on marine organisms.

\section{Acknowledgments}

We thanks Mr. David Chang for manuscript preparation, Miss Fahsai Thai-on, Miss Nittaya Jaerem, Miss Hawa Phoonpherm, Miss Kanchanid Panjareon, Miss Chanunchida Phitchayanitinai, students and teachers from Samsenwittayalai School for helping with field work. This work was supported in part by Samsenwittayalai school and the Center of Excellence for Ecoinformatics, Walailak University.

\section{References}

Andrady, A.L. (2011). Microplastics in the marine environment. Mar. Pollut. Bull. 62, 1596-1605.

Alkalay, R., Pasternak, G., \& Zask, A. (2007). Clean-coast index-a new approach for beach cleanliness assessment. Ocean Coast Manage, 50, 352-362.

Boucher, J. \& Friot, D. (2017). Primary microplastics in the Oceans: A global evaluation of sources. Gland, Switzerland: IUCN. 43pp.

Barnes, D.K., Galgani, F., Thompson, R.C., \& Barlaz, M. (2009). Accumulation and fragmentation of plastic debris in global environments. Philos. Trans. Roy. Soc.B: Biol. Sci. 364 (1526), $1985-$ 1998.

Cheshire, A.C., Adler, E., Barbiere, J., Cohen, Y., Evans, S., Jarayabhand, S., Jeftic, L., Jung, R.T., Kinsey, S., Kusui, E.T., Lavine, I., Manyara, P., Oosterbaan, L., Pereira, M.A., Sheavly, S., Tkalin, A., Varadarajan, S., Wenneker, B., \& Westphalen, G. (2009). UNEP/IOC guidelines on survey and monitoring of marine litter. UNEP regional seas reports and studies No. 186, IOC Technical Series. (No. 83, 120 p). 
Dawarah, K., \& Devipriya, S.P. (2019). Microplastic prevalence in the beaches of Puducherry, India and its correlation with fishing and tourism/recreational activities. Mar. Pollut. Bull. 148, 123133.

Davis, W., \& Murphy, A.G. (2015). Plastic in surfacewaters of the inside passage and beaches of the Salish sea in Washington state. Mar. Pollut. Bull. 97 (1-2), 169-177.

Depledge, M.H., Galgani, F., Panti, C., Caliani, I., Casini, S., \& Fossi, M.C. (2013). Plastic litter in the sea. Mar. Environ. Res. 92, 279-281.

Galgani, F., Hanke, G., \& Maes, T. (2015). Global distribution, composition and abundance of marine litter. In: Bergmann, M., Gutow, L., Klages, M. (Eds.), Marine Anthropogenic Litter. Springer, Berlin, pp. 29-56.

Hirai, H., Takada, H., Ogata, Y., Yamashita, R., Mizukawa, K., Saha, M., \& Ward, M.W. (2011). Organic micropollutants in marine plastics debris from the open ocean and remote and urban beaches. Mar. Pollut. Bull. 62 (8), 1683-1692.

Horton, A.A., Svendsen C., Williams, R.J., Spurgeon, D.J., \& Lahive, E. (2017). Large microplastic particles in sediments of tributaries of the River Thames, UK- Abundance, sources and methods for effective quantification. Mar. Pollut. Bull. 114, 218-226.

Jambeck, J.R., Geyer, R., Wilcox, C., Siegler, T.R., Perryman, M., Andrady, A., Narayan, R., \& Law, K.L. (2015). Plastic waste inputs from land into the ocean. Science 347, 768-771.

McDermid, K.J., \& McMullen, T.L. (2004). Quantitative analysis of small-plastic debris on beaches in the Hawaiian archipelago. Mar. Pollut. Bull. 48 (7), 790-794.

Portman, M.E., \& Brennan, R.E. (2017). Marine litter from beach-based sources: case study of an Eastern Mediterranean coastal town. Waste Manag. 69, 535-544.

UNEP (2016). Marine plastic debris and microplastics - Global lessons and research to inspire action and guide policy change. United Nations Environment Programme, Nairobi. Web site: http://hdl.handle.net/20.500.11822/7720

Vianello, A., Boldrin, A., Guerriero, P., Moschino, V., Rella, R., Sturaro, A., \& Da Ros, L. (2013). Microplastic particles in sediments of Lagoon of Venice, Italy: first observations on occurrence, spatial patterns and identification. Estuar. Coast. Shelf Sci. 130, 54-61. 